\title{
The Importance of Neutrophil to Lymphocyte Ratio and Platelet to Lymphocyte Ratio in Predicting the Appearance of the Rectal Stenosis or Rectal Obstruction in Patients with Rectal Adenocarcinomas
}

\author{
IOANA HALMACIU ${ }^{1}$, BOGDAN ANDREI SUCIU, ${ }^{1,2 *}$, VLAD VUNVULEA ${ }^{1}$, \\ MIRCEA GABRIEL MURESAN ${ }^{1,2}$, FLORENTINA CRISTINA SCARLAT ${ }^{1}$, \\ CALIN MOLNAR ${ }^{2}$, NICOLAE BACALBASA ${ }^{3}$, KLARA BRINZANIUC ${ }^{1}$, SEPTIMIU VOIDAZAN ${ }^{4}$ \\ ${ }^{1}$ University of Medicine, Pharmacy, Science and Technology Tirgu Mures Department of Anatomy, 38 Gheorghe \\ Marinescu Str., 540142, Romania \\ ${ }^{2}$ University of Medicine, Pharmacy, Science and Technology Tirgu Mures, Department of Surgery, 38 Gheorghe \\ Marinescu Str., 540142, Romania \\ ${ }^{3}$ Carol Davila University of Medicine and Pharmacy, Center of Excellence in Translational Medicine, Fundeni Clinical \\ Institute, 8 Eroii Sanitari Str., 050474, Bucharest, Romania \\ ${ }^{4}$ University of Medicine, Pharmacy, Science and Technology Tirgu Mures, Department of Epidemiology, 38 Gheorghe \\ Marinescu Str., 540142, Romania
}

\begin{abstract}
The purpose of this study was to establish a correlation between markers of inflammation and the risk of rectal stenosis or obstruction, in patients with rectal adenocarcinomas. We performed a retrospective observational study on 188 patients diagnosed with rectal adenocarcinomas. We attempted to establish a correlation between the neutrophils to lymphocyte ratio(NLR), platelet to lymphocyte ratio(PLR) levels and the presence of rectal stenosis or rectal obstruction. From 188 patients included in the study, 65 patients had stenotic tumors (34.57\% of cases) and 10 patients had occlusive tumors (5.31\% of cases). We obtained a statistically significant correlation between the blood levels of neutrophils, lymphocytes, platelets, and the existence of rectal stenosis. $(p<0.05)$. The cutoff value of NLR that correlates with the presence of rectal stenosis was 2.5 (95\% CI: 0.426-0.574, AUC: 0.500). As for PLR, the cutoff value correlated with the presence of rectal stenosis was 106,522 (95\% CI: 0.428-0.575, AUC: 0.502). We established a statistically significant correlation between NLR, PLR and rectal obstruction ( $p<0.05)$. The cutoff value of the NLR that correlates with the presence of rectal obstruction was 4.633 (95\%CI: 0.614-0.751, AUC: 0.685). As for $P L R$, the cutoff value correlated with the presence of rectal stenosis was 345.05 (95\% CI: 0.673-0.803, AUC: 0.742). Our study shows that there is a statistically significant correlation between NLR and PLR and the risk of rectal obstruction in patients with adenocarcinomas. It is still necessary to conduct prospective studies on much larger lots of patients to determine the NLR and PLR values that can predict rectal stenosis as well as rectal obstruction.
\end{abstract}

Keywords: neutrophil to lymphocyte ratio, platelet to lymphocyte ratio, rectal adenocarcinoma

Colo-rectal cancer is currently the second most common form of cancer in men, and the third most common form of cancer in wome [1]. In recent years, more and more studies have been published in the literature on the topic of the importance of inflammation mediators as prognostic factors in the pathogenesis of different types of cancers. It is known that colo-rectal malignancies are infiltrated by inflammatory cells, such as B lymphocytes, T lymphocytes, macrophages or natural killer cells [2,3]. These inflammatory cells produce cytokines as well as mediators of inflammation, which will cause a systemic inflammatory response. [4] Thus, the importance of inflammatory response in the growth of various tumors, including colorectal cancer, has been proven [5,6]. This inflammatory reaction also stimulates tumor angiogenesis and metastasis [7,8].

With the awareness of systemic inflammatory response in the pathogenesis of rectal cancer in recent years, more and more researchers have studied the importance as prognostic factors of markers related to inflammatory syndrome in patients with rectal cancer. Thus, at present, the most important markers studied are: the ratio of serum neutrophils to lymphocyte levels (NLR), as well as the relationship between serum platelet and lymphocyte levels (PLR) [9,10]. Although the vast majority of published studies currently recognize the importance of these biomarkers as prognostic factors, there is controversy in the literature as to the importance of prognostic factors of inflammation markers in rectal cancer patients [11].

*email: suciubogdanandrei@yahoo.com 
The aim of the present study was to assess the existence of correlations between NLR, PLR and some pathogenic factors such as: tumor stage, vascular invasion, nervous invasion, locally advanced tumor status, in patients with rectal cancer, relying on the experience of a medical center in south-eastern Europe.

\section{Experimental part}

In this study we used the cases database of the Surgery Clinic No. 1 of the Tîrgu Mureş University hospital, Romania. We performed a retrospective observational study over a period of 18 months between 1.10 .2016 and 31.03.2018. We introduced 188 patients diagnosed with rectal adenocarcinomas who were operated in this clinic. The data used in the study was obtained from the clinical observation sheets of the patients as well as from the results of the histopathological examinations from the surgical resections.

In all operated patients who were not in the stage of intestinal occlusion, recto-sigmoid resection with colo-rectal anastomosis was performed. In patients with intestinal occlusion, recto-sigmoid resection was performed with externalization of the proximal colon in terminal colostomy and closure of the distal rectum. For all patients enrolled in the study we studied the following parameters: patients age, patients sex, stenotic or occlusive character of the tumor formation, tumor stage (according to TNM and Dukes classification of rectal cancer), degree of differentiation of the tumor formation, vascular invasion, perineural invasion, as well as serum levels of neutrophils, lymphocytes and platelets, NLR and PLR. It was considered that the tumor was stenotic if intraoperative, the diameter of the rectum proximal to the tumor was greater than the diameter of the rectum distal to the tumor. It was also considered that the tumor was occlusive if the patient had signs of intestinal obstruction.

Qualitative data was presented as counts and percentages. The association between qualitative variables was assessed using the Chi-square test or the Fisher exact test. Quantitative data was presented as mean and standard deviation (for normally distributed data) and median/min-max (for abnormally distributed data) To check for differences between two independent groups of quantitative data, the t-Student test and Mann Whitney test were applied. The stenosis/obstruction status was assessed against several explanatory variables. The relationship between the stenosis/obstruction status and those explanatory variables was assessed with binomial logistic regression as appropriate statistical methods. In development of regression multivariate model, we selected all variables with pvalue less than 0.05 in univariate regression analysis along with all variables of known clinical importance. Results were presented as coefficients/odds ratios and 95\% CI. The ROC analysis was used to establish NLR and PLR cutoff values, as well as the area under curve (AUC), sensitivity, specificity, and $\mathrm{p}$ value for each parameter.

For logistic regression analysis, the dependent variable was considered the stenosis/obstruction status, coded, the risk variant being coded with 1 . The independent variables were the ratios, NLR and PLR. We initially set a cutoff value or prediction level by individually calculating the ROC curves according to the stenosis/obstruction status.

For all the statistical tests the significance level alpha was set at 0.05 and the two-tailed $p$ value was computed. We used the SPSS statistical software package 20.0 (SPSS, Inc., Chicago, IL, USA) for all statistical analyses.

\section{Results and discussions}

From the statistical analysis we note that from the 188 patients studied, 118 patients were men (62.76\%) and 70 were women (37.24\%). The mean age of patients studied was 66.84 years, with the range between 40 and 89 years. In the studied group, 65 patients had stenotic tumors (34.57\% of the cases) and 10 patients had obstructive tumors (5.31\% of cases).

Table 1

THE DISTRIBUTION OF INDEPENDENT VARIABLES OF INTEREST IN STUDY, REGARDING

\begin{tabular}{|c|c|c|c|}
\hline \multirow[t]{2}{*}{ Variables } & \multicolumn{2}{|c|}{ STENOSIS } & \multirow{2}{*}{$\mathrm{P}$ value } \\
\hline & $\begin{array}{c}\text { YES } \\
(65-34.5 \%)\end{array}$ & $\begin{array}{c}\text { NO } \\
(123-65.5 \%)\end{array}$ & \\
\hline Age, years, mean \pm SD & $66.8 \pm 10.6$ & $66.7 \pm 9.5$ & $0.94 * * *$ \\
\hline Sex, male, no (\%) & $38(58.5)$ & $80(65.0)$ & $\begin{array}{c}0.37 * \\
\text { HR: } 1.32 \\
\text { (CI95\%:0.71-2.45) }\end{array}$ \\
\hline PTL, mean \pm SD & $328.94 \pm 115.49$ & $123 \pm 24.2$ & $0.002 * * *$ \\
\hline LYM, mean \pm SD & $2.15 \pm 1.74$ & $1.58 \pm 0.77$ & $0.001 * * *$ \\
\hline NEUT, mean \pm SD & $3.65 \pm 1.52$ & $4.78 \pm 1.64$ & $0.001 * * *$ \\
\hline \multicolumn{4}{|l|}{$\mathrm{Pt}$} \\
\hline 1 & $10(15.4)$ & $20(16.3)$ & $\mathrm{P}>0.05^{*}$ \\
\hline 2 & $3(4.6)$ & $16(13.0)$ & $\mathrm{P}>0.05^{*}$ \\
\hline 3 & $33(50.8)$ & $57(46.3)$ & $\mathrm{P}>0.05^{*}$ \\
\hline $4 a$ & $13(20.0)$ & $26(21.1)$ & $\mathrm{P}>0.05^{*}$ \\
\hline $4 \mathrm{~b}$ & $6(9.2)$ & $4(3.3)$ & $\mathrm{P}>0.05^{*}$ \\
\hline $\mathrm{pN}$ & & & \\
\hline
\end{tabular}




\begin{tabular}{|c|c|c|c|}
\hline 0 & $28(43.1)$ & $69(56.1)$ & $\mathrm{P}>0.05^{*}$ \\
\hline $1 \mathrm{a}$ & $14(21.5)$ & $20(16.3)$ & $\mathrm{P}>0.05^{*}$ \\
\hline $1 \mathrm{~b}$ & $5(7.7)$ & $4(3.3)$ & $\mathrm{P}>0.05^{*}$ \\
\hline $1 \mathrm{c}$ & $2(3.1)$ & $0(0.0)$ & $\mathrm{P}>0.05^{*}$ \\
\hline $2 \mathrm{a}$ & $10(15.4)$ & $19(15.4)$ & $\mathrm{P}>0.05^{*}$ \\
\hline $2 \mathrm{~b}$ & $5(7.7)$ & $11(8.9)$ & $\mathrm{P}>0.05^{*}$ \\
\hline $4 \mathrm{a}$ & $1(1.5)$ & $0(0.0)$ & $\mathrm{P}>0.05^{*}$ \\
\hline \multicolumn{4}{|l|}{$\mathrm{pM}$} \\
\hline 0 & $60(92.3)$ & $117(95.1)$ & $\mathrm{P}>0.05^{*}$ \\
\hline 1 & $1(1.5)$ & $1(0.8)$ & $\mathrm{P}>0.05^{*}$ \\
\hline $1 \mathrm{a}$ & $4(6.2)$ & $5(4.1)$ & $\mathrm{P}>0.05^{*}$ \\
\hline $\begin{array}{c}\text { Vascular invasion } \\
\text { YES }\end{array}$ & $20(30.8)$ & $34(27.6)$ & $\begin{array}{c}0.62 * \\
\mathrm{HR}=1.16 \\
(\mathrm{CI} 95 \%: 0.60-2.24)\end{array}$ \\
\hline $\begin{array}{c}\text { Perineural invasion } \\
\text { YES }\end{array}$ & $27(41.5)$ & $40(32.5)$ & $\begin{array}{c}0.26^{*} \\
\mathrm{HR}=1.47 \\
(\mathrm{CI} 95 \%: 0.79-2.74)\end{array}$ \\
\hline \multicolumn{4}{|l|}{ Tumor differentiation } \\
\hline Inalt & $13(20.0)$ & $17(13.8)$ & $\mathrm{P}>0.05^{*}$ \\
\hline Moderate & $12(18.5)$ & $20(16.3)$ & $\mathrm{P}>0.05^{*}$ \\
\hline Low & $40(61.5)$ & $86(69.9)$ & $\mathrm{P}>0.05^{*}$ \\
\hline \multicolumn{4}{|c|}{ Stage -TNM classification } \\
\hline $\mathrm{I}$ & $3(4.6)$ & $15(12.2)$ & $\mathrm{P}>0.05^{*}$ \\
\hline IIA & $13(20.0)$ & $36(39.3)$ & $\mathrm{P}>0.05^{*}$ \\
\hline IIB & $10(15.4)$ & $13(10.6)$ & $\mathrm{P}>0.05^{*}$ \\
\hline IIC & $1(1.5)$ & $2(1.6)$ & $\mathrm{P}>0.05^{*}$ \\
\hline IIIA & $10(15.4)$ & $18(14.6)$ & $\mathrm{P}>0.05^{*}$ \\
\hline IIIB & $15(23.1)$ & $21(17.1)$ & $\mathrm{P}>0.05^{*}$ \\
\hline IIIC & $8(12.3)$ & $12(9.8)$ & $\mathrm{P}>0.05^{*}$ \\
\hline IVA & $5(7.7)$ & $6(4.9)$ & \\
\hline \multicolumn{4}{|c|}{ Stage -Dukes classification } \\
\hline 0 & $5(7.7)$ & $6(4.9)$ & $\mathrm{P}>0.05^{*}$ \\
\hline $\mathrm{A}$ & $3(4.6)$ & $15(12.2)$ & $\mathrm{P}>0.05^{*}$ \\
\hline $\mathrm{B}$ & $24(36.9)$ & $51(41.5)$ & $\mathrm{P}>0.05^{*}$ \\
\hline $\mathrm{C}$ & $33(50.8)$ & $51(41.5)$ & $\mathrm{P}>0.05^{*}$ \\
\hline NLR & $3.04(0.63-31.5)$ & $3.08(1.09-20.8)$ & $0.99 * *$ \\
\hline PLR & $182.4(27.9-1146.5)$ & $166.1(59.3-894.9)$ & $0.96^{* *}$ \\
\hline
\end{tabular}

We used: *Chi square test or Fisher exact test, ***Student test and **Mann Whitney test

From the analysis of the data presented in Table 1, it can be observed that, regarding the correlation of the independent variables studied and the stenotic character of the tumor, the only statistically significant variables are serum levels of lymphocytes, neutrophils and platelets. In the studied group in patients with stenotic tumors, we achieved an average serum level of neutrophils of $3650 / \mathrm{mm}^{3}$, an average lymphocyte level of $2150 / \mathrm{mm}^{3}$ and a mean serum platelet level of $328940 / \mathrm{mm}^{3}$. We have not obtained statistically significant correlations between the presence of tumoral rectal stenosis and the staging of rectal cancer by TNM and Dukes, nor in the case of vascular or perineural invasion.

We also performed univariate regression analysis with the stenosis dependent variable (binary code 1 and 0 ), but we did not identify significant associations between NLR, respectively PLR and the presence of tumoral rectal stenosis. (Table 2) Taking this into account, we did not consider it necessary to perform multivariate analysis.

Table 2

UNIVARIATE REGRESSION FOR CONSIDERED INDEPENDENT VARIABLE

\begin{tabular}{|c|c|c|c|c|c|c|c|}
\hline Variables & B & S.E. & Wald & P value & \multirow{2}{*}{ OR crude } & \multicolumn{2}{|c|}{ 95\% CI for OR crude } \\
\cline { 5 - 8 } & & & & & & Lower & Upper \\
\hline NLR & 0.038 & 0.042 & 0.789 & 0.374 & 1.038 & 0.955 & 1.129 \\
\hline PLR & 0.001 & 0.001 & 0.452 & 0.501 & 1.001 & 0.999 & 1.002 \\
\hline
\end{tabular}

Next, we calculated the cutoff value for the NLR and PLR ratio versus the stenotic character of the tumor. In the NLR case, we obtained a cutoff value of 2.5, and in the case of PLR the cutoff value was 106.52. Thus we calculated for each ratio, the predictive degree of the stenotic character of the tumor. We also determined the ROC curves and performance parameters, characterized by sensitivity and specificity. We noticed that in the NLR case, a cutoff value of 2.5 , a sensitivity of $40 \%$, a specificity of $70.7 \%$ and AUC of $50.0 \%$, (95\% CI: 42.6-57.4) there is prediction that the rectal tumor is stenotic (Figure 1, Table 3) 


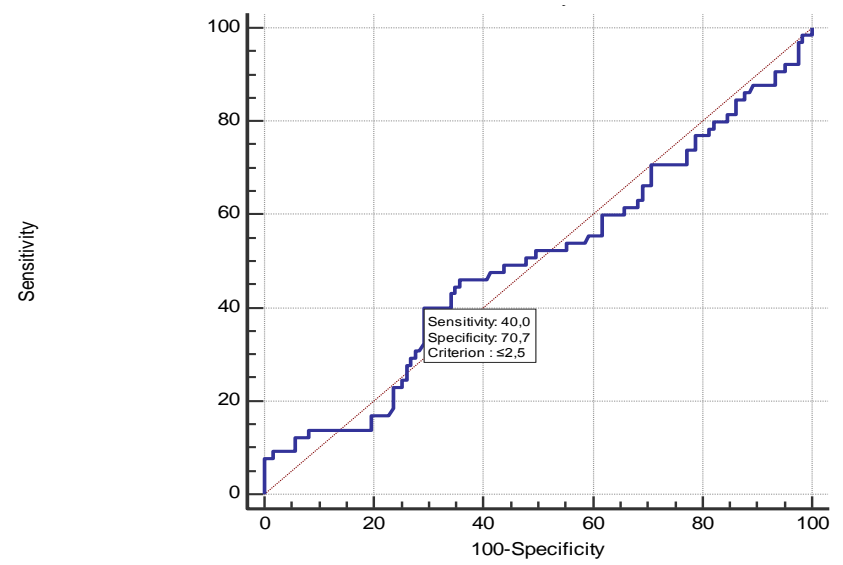

Fig. 1. ROC curve for cutoff value of NLR of 2.5

Table 3

ROC CURVE FOR CUTOFF VALUE OF NLR

\begin{tabular}{|c|c|}
\hline Variable & NLR \\
\hline Classification variable & Stenozat \\
\hline Area under the ROC curve (AUC) & 0,500 \\
\hline Standard Error ${ }^{a}$ & 0,0460 \\
\hline $95 \%$ Confidence Interval ${ }^{\mathrm{b}}$ & 0,426 to 0,574 \\
\hline z statistic & 0,00272 \\
\hline Significance level P (Area $=0.5)$ & 0,9978 \\
\hline
\end{tabular}

In the case of PLR, a cutoff value of 106,522 correlated with the stenotic character of the tumor assured a sensitivity of $23.1 \%$ and a specificity of $87.8 \%$, the AUC was $50.2 \%$ (95\% CI: $42.8-57.5$ ). So, for PLR values above 106,522 , there is a possibility that the rectal tumor is stenotic. (Figure 2, Table 4)

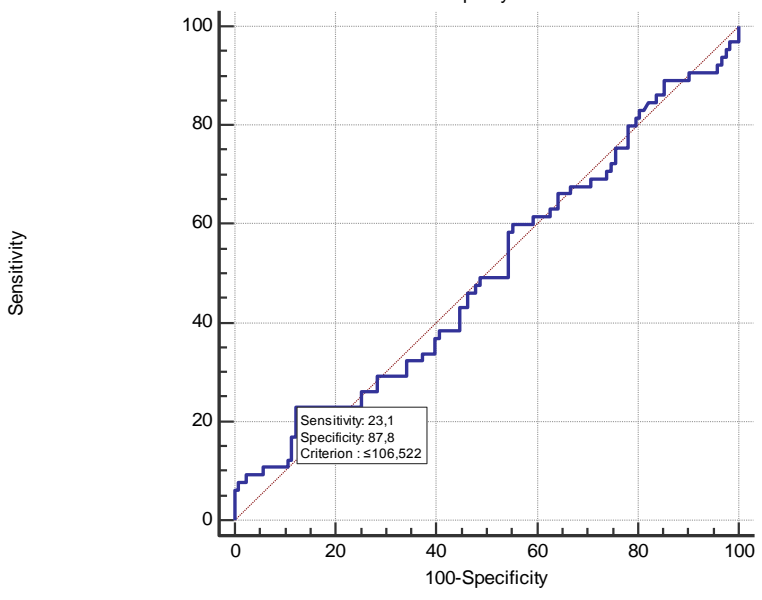

Fig. 2. ROC curve for cutoff value of PLR of 106.522

Table 4

ROC CURVE FOR CUTOFF VALUE OF PLR

\begin{tabular}{|c|c|}
\hline Variable & PLR \\
\hline Classification variable & Stenozat \\
\hline Area under the ROC curve (AUC) $^{\text {a }}$ & 0,502 \\
\hline Standard Error $^{\text {a }}$ Confidence Interval $^{\text {b }}$ & 0,0454 \\
\hline z statistic $^{\text {95\% }}$ & 0,428 to 0,575 \\
\hline Significance level P $($ Area $=0.5)$ & 0,0386 \\
\hline
\end{tabular}

Of the 188 patients included in the study, 10 patients experienced intestinal obstruction (5.31\% of cases). We have noticed that, regarding the studied parameters and the correlation with intestinal obstruction in patients with rectal adenocarcinomas, NLR and PLR correlates statistically with intestinal obstruction ( $\mathrm{p}<0.05)$. Also, pT3 and pT4b stages correlate statistically with intestinal obstruction. ( $\mathrm{P}<0.005)$. Additionally, the serum lymphocyte level 
correlates statistically with intestinal occlusion in rectal cancer patients. ( $\mathrm{p}<0.05)$. However, in the case of TNM, respectively Dukes staging of rectal cancer or vascular and perineural invasion, we did not obtain statistically significant correlations. The results are shown in Table 5.

Table 5

THE DISTRIBUTION OF INDEPENDENT VARIABLES OF INTEREST IN STUDY AND THE ASSOCIATION OF OCCLUSIVE RECTAL CANCER

\begin{tabular}{|c|c|c|c|}
\hline \multirow[t]{2}{*}{ Variables } & \multicolumn{2}{|c|}{ OBSTRUCTION } & \multirow{2}{*}{ P value } \\
\hline & $\begin{array}{c}\text { YES } \\
(10-5.31 \%)\end{array}$ & $\begin{array}{c}\mathrm{NO} \\
(178-94.68 \%) \\
\end{array}$ & \\
\hline Age, years, mean \pm SD & $70 \pm 9.17$ & $66.6 \pm 9.95$ & $0.29 * * *$ \\
\hline Sex, male, no $(\%)$ & $6(60.0)$ & $112(62.9)$ & $\begin{array}{c}0.85 * \\
\text { HR:1.13 (CI95\%:0.30- } \\
4.15)\end{array}$ \\
\hline PTL, mean \pm SD & $336.8 \pm 98.1$ & $284.9 \pm 100.1$ & $0.11^{* * *}$ \\
\hline LYM, mean \pm SD & $1.15 \pm 0.61$ & $1.82 \pm 0.24$ & $0.008 * * *$ \\
\hline NEUT, mean \pm SD & $6.51 \pm 3.57$ & $5.26 \pm 2.49$ & $0.30 * * *$ \\
\hline \multicolumn{4}{|l|}{ pT } \\
\hline 1 & $1(10)$ & $29(16.3)$ & $\mathrm{P}>0.05^{*}$ \\
\hline 2 & $0(0)$ & $19(10.7)$ & $\mathrm{P}>0.05^{*}$ \\
\hline 3 & $4(10)$ & $86(48.3)$ & 0.001* \\
\hline $4 \mathrm{a}$ & $1(10)$ & $38(21.3)$ & $\mathrm{P}>0.05^{*}$ \\
\hline $4 \mathrm{~b}$ & $4(40)$ & $6(3.4)$ & 0.001* \\
\hline \multicolumn{4}{|l|}{$\mathrm{pN}$} \\
\hline 0 & $3(30)$ & $94(52.8)$ & $\mathrm{P}>0.05^{*}$ \\
\hline $1 \mathrm{a}$ & $3(30)$ & $31(17.4)$ & $\mathrm{P}>0.05^{*}$ \\
\hline $1 \mathrm{~b}$ & $1(10)$ & $8(4.5)$ & $\mathrm{P}>0.05^{*}$ \\
\hline $1 \mathrm{c}$ & $1(10)$ & $1(0.6)$ & $\mathrm{P}>0.05^{*}$ \\
\hline $2 \mathrm{a}$ & $2(20)$ & $27(15.2)$ & $\mathrm{P}>0.05^{*}$ \\
\hline $2 b$ & $0(0)$ & $16(9.0)$ & $\mathrm{P}>0.05^{*}$ \\
\hline $4 \mathrm{a}$ & $0(0)$ & $1(0.6)$ & $\mathrm{P}>0.05^{*}$ \\
\hline \multicolumn{4}{|l|}{$\mathrm{pM}$} \\
\hline 0 & $9(90.0)$ & $168(94.4)$ & $\mathrm{P}>0.05$ \\
\hline 1 & $0(0)$ & $2(1.1)$ & $\mathrm{P}>0.05$ \\
\hline $1 \mathrm{a}$ & $1(10)$ & $8(4.5)$ & $\mathrm{P}>0.05$ \\
\hline $\begin{array}{c}\text { Vascular invasion } \\
\text { YES }\end{array}$ & $2(20.0)$ & $52(29.2)$ & $\begin{array}{c}0.53 * \\
\mathrm{HR}=0.60 \\
(\mathrm{CI} 95 \%: 0.12-2.95) \\
\end{array}$ \\
\hline $\begin{array}{c}\text { Perineural invasion } \\
\text { YES }\end{array}$ & $5(50)$ & $62(34.8)$ & $\begin{array}{c}0.33 * \\
\mathrm{HR}=1.87 \\
(\mathrm{CI} 95 \%: 0.52-6.71)\end{array}$ \\
\hline \multicolumn{4}{|l|}{ GRADE } \\
\hline High & $1(10)$ & $29(16.3)$ & $\mathrm{P}>0.05^{*}$ \\
\hline Moderate & $3(30)$ & $29(16.3)$ & $\mathrm{P}>0.05^{*}$ \\
\hline Low & $6(60)$ & $120(67.4)$ & $\mathrm{P}>0.05^{*}$ \\
\hline \multicolumn{4}{|l|}{ TNM stage } \\
\hline $\mathrm{I}$ & $0(0)$ & $18(10.1)$ & $\mathrm{P}>0.05^{*}$ \\
\hline IIA & $1(10)$ & $48(27.0)$ & $\mathrm{P}>0.05^{*}$ \\
\hline IIB & $2(20)$ & $21(11.8)$ & $\mathrm{P}>0.05^{*}$ \\
\hline IIC & $0(0)$ & $3(1.7)$ & $\mathrm{P}>0.05^{*}$ \\
\hline IIIA & $1(10)$ & $27(15.2)$ & $\mathrm{P}>0.05^{*}$ \\
\hline IIIB & $3(30)$ & $33(18.5)$ & $\mathrm{P}>0.05^{*}$ \\
\hline IIIC & $2(20)$ & $18(10.1)$ & $\mathrm{P}>0.05^{*}$ \\
\hline IVA & $1(10)$ & $10(5.6)$ & $\mathrm{P}>0.05^{*}$ \\
\hline \multicolumn{4}{|l|}{ Dukes } \\
\hline 0 & $1(10)$ & $10(5.6)$ & $\mathrm{P}>0.05^{*}$ \\
\hline $\mathrm{A}$ & $0(0)$ & $18(10.1)$ & $\mathrm{P}>0.05^{*}$ \\
\hline $\mathrm{B}$ & $3(30.0)$ & $72(40.4)$ & $\mathrm{P}>0.05^{*}$ \\
\hline $\mathrm{C}$ & $6(60.0)$ & $78(43.8)$ & $\mathrm{P}>0.05^{*}$ \\
\hline NLR & $5.37(1.83-31.5)$ & $3.02(0.63-3.83)$ & $0.04 * *$ \\
\hline PLR & $377.28(113.15-1132.5)$ & $161.54(27.3-209.9)$ & $0.01 * *$ \\
\hline
\end{tabular}

We used: *Chi square test or Fisher exact test, $* * *$ Student test and $* *$ Mann Whitney test 
We then performed the univariate regression analysis with the obstruction dependent variable (binary code 1 and 0 ), and we identified significant associations. We have noticed that the occurrence of rectal obstruction in rectal cancer patients is influenced by NLR and PLR. $(\mathrm{p}<0.05)$ The results are shown in Table 6.

Table 6

UNIVARIATE REGRESSION FOR CONSIDERED INDEPENDENT VARIABLE

\begin{tabular}{|c|c|c|c|c|c|c|c|}
\hline Variables & B & S.E. & Wald & P value & OR crude & \multicolumn{2}{|c|}{$95 \%$ CI for OR crude } \\
\cline { 5 - 8 } & & & & & & Lower & Upper \\
\hline NLR & 0.167 & 0.061 & 7.576 & $\mathbf{0 . 0 0 6}$ & 1.182 & 1.049 & 1.332 \\
\hline PLR & 0.004 & 0.001 & 9.892 & $\mathbf{0 . 0 0 2}$ & 1.004 & 1.002 & 1.006 \\
\hline
\end{tabular}

In multivariate analysis, we noticed that occlusive rectal cancer is only influenced by PLR, not NLR ( $\mathrm{p}<0.05)$. The results are shown in Table 7.

Table 7

MULTIVARIATE REGRESSION FOR CONSIDERED INDEPENDENT VARIABLE

\begin{tabular}{|c|c|c|c|c|c|c|c|}
\hline & B & S.E. & Wald & P value & OR crude & \multicolumn{2}{|c|}{ 95\% C.I.for OR crude } \\
\cline { 5 - 7 } & & & & & & Lower & Upper \\
\hline NLR & 0.091 & 0.070 & 1.708 & 0.191 & 1.096 & 0.955 & 1.257 \\
\hline PLR & 0.003 & 0.002 & 3.485 & 0.042 & 1.003 & 1.000 & 1.006 \\
\hline
\end{tabular}

We calculated the cutoff value of the NLR that correlates with the presence of intestinal obstruction, and we noticed that NLR values greater than 4.633 were associated with the presence of rectal obstruction with a sensitivity of $60 \%$ and a specificity of $77 \%$, the AUC was of $68.5 \%$, (95\% CI: $61.4 \%-75.1 \%$ ). (Figure 3 ).

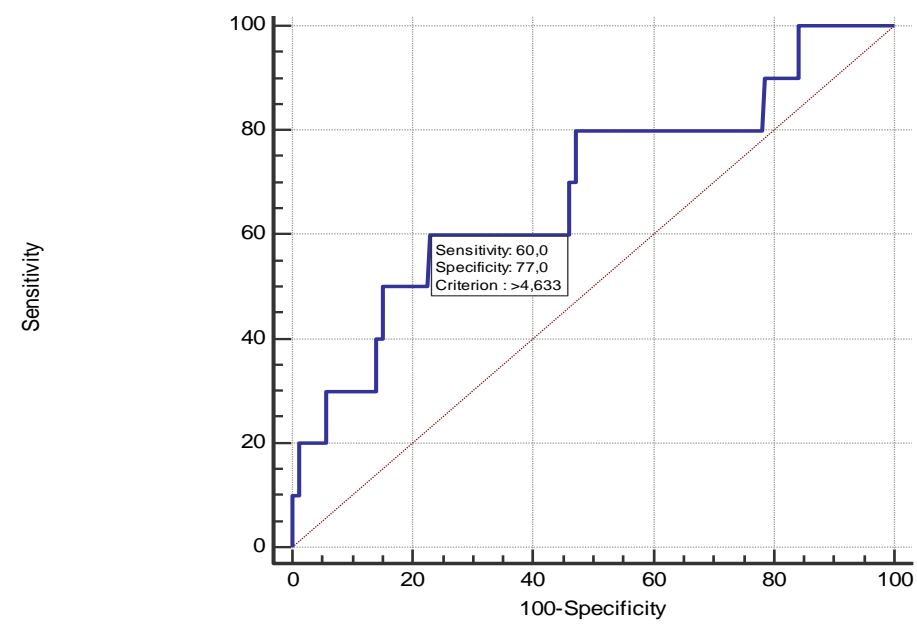

Fig. 3. ROC curve for cutoff value of NLR of 4.633

Table 8

ROC CURVE FOR CUTOFF VALUE OF NLR AND OCCLUSIVE STATUS OF RECTAL CANCER

\begin{tabular}{|c|c|}
\hline \multicolumn{1}{|c|}{ Variable } & NLR \\
\hline Classification variable & Occlusive \\
\hline Area under the ROC curve (AUC) & 0,685 \\
\hline Standard Error a & 0,0997 \\
\hline $95 \%$ Confidence Interval $^{\text {b }}$ & 0,614 to 0,751 \\
\hline z statistic & 1,859 \\
\hline Significance level P (Area=0.5) & 0,0630 \\
\hline
\end{tabular}

In the case of PLR, in the studied lot, we established a cutoff value of 345.05, values higher than 345.05 associated with occlusive rectal cancer with a sensitivity of $60 \%$ and a specificity of $88.8 \%$, AUC was $74.2 \%$, (95\% CI: 67.3 80.3) (Figure 4, Table 9). 


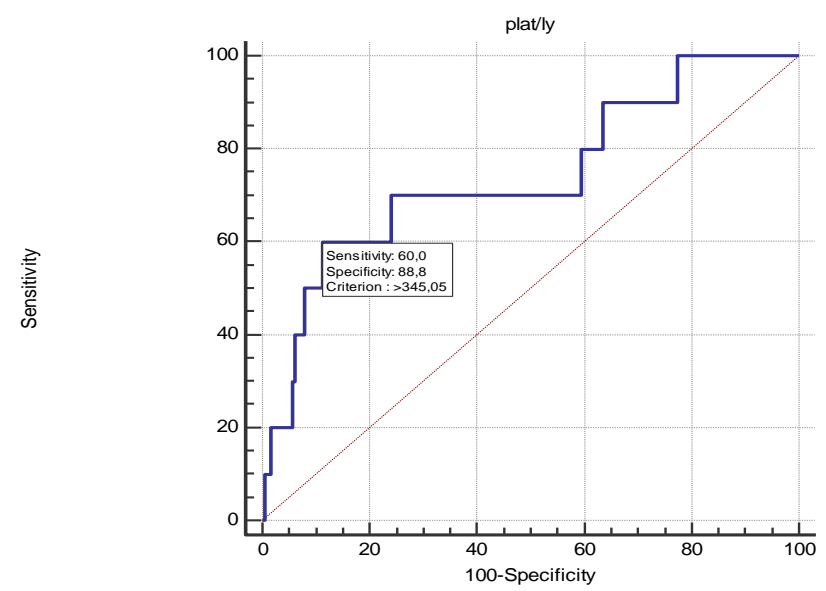

Fig.4. ROC curve for cutoff value of PLR of 345.05

Table 9

ROC CURVE FOR CUTOFF VALUE OF PLR AND OCCLUSIVE STATUS OF RECTAL CANCER

\begin{tabular}{|c|c|}
\hline \begin{tabular}{|l|}
\hline Variable \\
\hline Classification variable
\end{tabular} PLR \\
\hline Area under the ROC curve (AUC) \\
\hline Standard Error ${ }^{\text {a }}$ & 0,742 \\
\hline $95 \%$ Confidence Interval $^{\text {b }}$ & 0,0944 \\
\hline z statistic $^{\text {Significance level P (Area }=0.5)}$ & 0,673 to 0,803 \\
\hline
\end{tabular}

Currently, the most commonly used staging in rectal cancer patients in clinical practice is the TNM classification and the Dukes classification. Instead, it has been noticed that patients at the same clinical stage of the disease may have a completely different evolution and survival over time. This is why many authors are trying to study the existence of possible biomarkers that better reflect the long-term prognosis of these patients [12]. With the development of individualized cancer treatment in patients with various types of neoplasia, the emergence of new biomarkers that can identify the prognosis of these patients has been established in clinical practice. In this regard, a multitude of genetic biomarkers have been developed that are studied in patients with rectal cancer $[13,14]$. These genetic biomarkers have the major disadvantage of being very expensive, and their widespread determination in neoplastic patients entails very high financial costs. Unlike genetic markers, determining serum levels of neutrophils, platelets and lymphocytes are routine tests that are performed in all of these patients and do not involve increased financial costs [15]. Also, it is well known the fact that the inflamation play an important role in the healing process [16-18].

Most studies published in recent years have highlighted the importance of inflammatory syndrome in the pathogenesis of various cancers, including colorectal cancer [19]. It has also been demonstrated that the severity of the systemic inflammatory syndrome affects the prognostic of these patients [20-22]. At the same time, some authors have proven that chronic inflammatory syndrome stimulates the growth of malignant tumors as well as the metastatic process [23,24]. Thus, many authors have tried to find new biomarkers that correlate with the prognosis of these patients. The most commonly studied biomarkers at present are NLR and PLR. [25,26]. Many authors argue that increased NLR values are associated with a poor prognosis for these patients, but so far the results are contradictory $[27,28]$. Unlike NLR, in the case of PLR, elevated values are associated with good prognosis. But the results are still contradictory because there are studies that show different results, probably due to the heterogeneity of the cases being studied [29-31].

In our study, we have not been able to establish a correlation between the presence of stenosis or rectal obstruction and tumor status, both in the TNM and in the Dukes classification. A particular aspect of our study is the fact that the lot we studied was very heterogeneous, with a small number of patients included in some tumor stages.

The authors who support the importance of the NLR as prognostic factor consider that neutrophils produce biological mediators that can stimulate the progression of various cancers, such as vascular endothelial growth factor. Also cytokines produced by tumor cells can induce neutrophilia [32,33]. At the same time, cytokines produced by tumor cells stimulate tumor progression as well as its metastasis. Besides that, lymphopenia can cause a decrease in $\mathrm{T}$ helper lymphocyte count. All these factors can influence the value of NLR [34-36]. On the other hand, it has been 
shown that platelet counts are usually associated with the progression of different cancers, which may influence the value of PLR [37-39].

It is known that rectal tumors that produce rectal stenosis or even cause rectal obstruction, in the vast majority of cases, are loco-regional advanced tumors. Many studies published in the literature attempt to study the existence of correlations between the prognosis of patients with rectal cancer and certain markers of inflammation. Therefore, in our study, we have tried to investigate the existence of a correlation between systemic inflammation markers represented by PLR and NLR in patients with rectal cancer and the existence of rectal stenosis or occlusion.

In our study, using the statistical software and based on ROC curves, we attempted to establish the cutoff value of the NLR that could be associated with the stenotic character of the tumor as well as rectal obstruction. Thus we noticed that at NLR values greater than 2.5 there is a statistical probability that the rectal tumor is stenotic, and at NLR values above 4.633 there is a fairly high statistical probability that the patient will present intestinal occlusion . In this regard, it is known that rectal tumors that determine an intestinal stenosis are usually loco-regional advanced tumors, which usually have a rather poor prognosis. A similar study was published by Shen in 2014, suggesting that NLR values above 2.8 are associated with a poor prognosis in patients with rectal cancer [40-42].

Regarding the PLR, there are other studies in the literature that have attempted to determine the cutoff value of PLR that is associated with a poor prognosis in patients with rectal cancer. Li publishes in 2016 a study that shows that patients with rectal cancer who have a PLR greater than 144 associates long-term poor prognosis [43]. The findings of this study overlap with those of our study, because in our group, at PLR values above 106,522, the rectal tumor is likely to be stenotic (sensitivity of $23.1 \%$, specificity of $87.8 \%$ ), and at values of PLR over 345.05 there is a probability that rectal cancer patients will have rectal obstruction (sensitivity of $60 \%$, specificity of $88.8 \%$ ).

In patients with rectal stenosis, we did not obtain a statistically significant correlation between tumor stage and tumor stenosis, but in patients with rectal obstruction we noticed that there was a statistically significant correlation between the existence of rectal obstruction and the stages of pT3, pT4b of the tumor. We did not achieve a statistically significant correlation for the stage pT4a of the tumor because we had few patients who were at this stage of the disease. Instead, we noticed that the blood levels of neutrophils, lymphocytes and platelets correlate statistically with rectal stenosis, and NLR and PLR correlates with rectal obstruction in rectal cancer patients in univariate analysis. In multivariate analysis, PLR only correlates with the presence of rectal obstruction, probably due to the relative number of cases studied. These results are due to the fact that, with the occurrence of intestinal obstruction in these patients, there is a local inflammatory reaction that can produce systemic effects.

Some of the factors that may limit the importance of our study include the possibility that patients undergoing the trial may exhibit co-morbidities that could influence the values of NLR or PLR. Such disorders may be atherosclerosis, metabolic syndrome, or the coexistence of other inflammatory conditions [44-46]. Even if we take into account these limitations of our study, our data shows that the values of NLR or PLR may be markers of the existence of a rectal stenosis or rectal obstruction in patients with rectal adenocarcinomas. Another factor that may limit the importance of the study is that even if we had introduced a relatively large number of patients in the trial, their distribution according to the tumor stage is quite heterogeneous, which may affect the final results.

\section{Conclusions}

Our study shows that there is a statistically significant correlation between NLR and PLR and the risk of rectal obstruction in patients with adenocarcinomas. It is still necessary to conduct prospective studies on much larger lots of patients to determine the NLR and PLR values that can predict rectal stenosis as well as rectal obstruction.

\section{References}

1.JEMAL A, BRAY F, CENTER MM, FERLAY J, WARD E, FORMAN D., CA. Cancer. J. Clin. 61,2011,nr.2.p.69-90

2.GALON J, FRIDMAN WH, PAGES F., Cancer Res 67,2007,nr.5,p.1883-1886

3.KIM IY, YOU SH, KIM YW., BMC Surg., 14,2014,p.94, doi: 10.1186/1471-2482-14-94

4.HUNG HY, CHEN JS, YEH CY, CHANGCHIEN CR, TANG R, HSIEH PS, TASI WS, YOU JF, YOU YT, FAN CW, WANG JY, CHIANG

JM., Int. J. Color. Dis., 26,2011,nr.8,p.1059-1065.

5.DIAKOS CI, CHARLES KA, MCMILLAN DC, CLARKE SJ., Lancet Oncol., 15,2014,nr.11,p.493-503

6.ZHAO J, XU J, ZHANG R., Med. Sci. Monit., 23,2017,p.4826-4833

7.NOZOE T., MATSUMATA T., KITAMURA M., SUGIMACHI K., Am. J. Surg., 176,1998,nr.4,p.335-338

8GUILLEM-LLOBAT P, DOVIZIO M, ALBERTI S, BRUNO A, PATRIGNANI P., Sem. Oncol., 41,2014,nr.3,p.385-396

9.SOKOLOV M, ANGELOV K, VASILEVA M, ATANASOVA MP, VLAHOVA A, TODOROV G., Onco. Targets. Ther., 8,2015,p.23292337

10SHIBUTANI M, MAEDA K, NAGAHARA H, OHTANI H, ISEKI Y, IKEYA T, SUGANO K, HIRAKAWA K., World. J. Surg. Oncol. 13,2015,p.194, doi: 10.1186/s12957-015-0609-3

11.PORTALE G, CAVALLIN F, VALDEGAMBERI A, FRIGO F, FISCON V., J. Gastrointest. Surg., 22,2018,nr.9,p.1611-1618

12.BENSON AB, SCHRAG D, SOMERFIELD MR, COHEN AM, FIGUEREDO AT, FLYNN PJ, KRZYZANOWSKA MK, MAROUN J, MCALLISTER P, VAN CUTSEM E, BROUWERS M, CHARETTE M, HALLER DG., J. Clin. Oncol., 22,2004,nr.16,p.3408-3419 13.CHOPRA N, TURNER NC., Lancet Oncol., 18,2017,nr.7,p.842-843

Rev. Chim. 71 no. 2 2020 https://revistadechimie.ro 
14.SCHERNBERG A, ESCANDE A, RIVIN DEL CAMPO E, DUCREUX M, NGUYEN F, GOERE D, CHARGARI C, DEUTSCH E., Radiother. Oncol., 122,2017,nr.1,p.137-145

15.VALLARD A, GARCIA MA, DIAO P, ESPENEL S, DE LAROCHE G, GUY JB, MRAD MB, RANCOULE C, KACZMAREK D, MURON T, PIGNÉ G, PORCHERON J, PEOC'H M, PHELIP JM, LANGRAND-ESCURE J, MAGNÉ N., Oncotarget, 9,2018,nr.32,p.2236822382

16.SUCIU BA., PAP Z., DÉNES L., BRÎNZANIUC K., COPOTOIU C., PÁVAI Z., Rom. J. Morphol. Embryol., 57,2016,nr.2,p.495-500.

17.BUD V., SUCIU BA., BUTIURCA V., BRÎNZANIUC K., COPOTOIU R., COPOTOIU C., SIN A., Rom. J. Morphol. Embryol., 54,2013,nr.1,p.115-119.

18.SUCIU BA., HALMACIU I., BUD V., COPOTOIU C., FODOR D., TRAMBITAS C., GODJA D., VUNVULEA V., MOLNAR C., BRINZANIUC K., Mat. Plast., 54,2017,nr.4,p.626-629

19.JESS T, RUNGOE C, PEYRIN-BIROULET L., Clin. Gastroenterol. Hepatol. 10,2012,nr.6,p.639-645

20.CAPUTO D, CARICATO M, COPPOLA A, LA VACCARA V, FIORE M, COPPOLA R., Cancer Invest., 34,2016,nr.9,p.1-12

21.SUCIU BA., HALMACIU I., FODOR D., TRAMBITAS C., GODJA D., CLIPA A., NICOLESCU C., BRINZANIUC K., VUNVULEA V., Mat. Plast., 55, no.3, 2018, p.380-384

22.HALMACIU I., SUCIU BA., TRAMBITAS C., VUNVULEA V., IVANESCU A., CLIPA A., ADASCALITEI P., BRINZANIUC K., FODOR D., Mat. Plast., 55, no. 3, 2018, p.414

223.WANG J, JIA Y, WANG N, ZHANG X, TAN B, ZHANG G, CHENG Y., J. Transl. Med., 12,2014,p.7, doi: 10.1186/1479-5876-12-7.

24.ZHOU WW, CHU YP, AN GY., Eur. Rev. Med. Pharmacol. Sci., 21,2017,nr23,p.5386-5391

25.CHAN J, CHAN DL, DIAKOS CI, ENGEL A, PAVLAKIS N, GILL A, CLARKE SJ., Ann. Surg., 265,2017,nr.3,p.539-546.

26.SZKANDERA J, PICHLER M, ABSENGER G, STOTZ M, ARMINGER F, WEISSMUELLER M, SCHABERL-MOSER R, SAMONIGG H, KORNPRAT P, STOJAKOVIC T, AVIAN A, GERGER A., Am. J. Surg., 208,2014,nr.2,p.210-214.

27.LINO-SILVA LS, SALCEDO-HERNÁNDEZ RA， RUIZ-GARCÍA EB， GARCÍA-PÉREZ L, HERRERA-GÓMEZ Á., Med. Arch., 70,2016,nr.4,p.256-260

28.DONG YW, SHI YQ, HE LW, SU PZ., Onco. Targets. Ther., 9,2016,p.3127-3134

29.JUNG SW, PARK IJ, OH SH, YEOM SS, LEE JL, YOON YS, KIM CW, LIM SB, LEE JB, YU CS, KIM JC., Oncotarget 8,2017,nr.35,p.59757-59765

30.GURZU S., JUNG I., COMSULEA M., KADAR Z., AZAMFIREI L., MOLNAR C., Diagn. Pathol., 8,2013,p.150. doi: 10.1186/1746-1596$8-150$

31.GURZU S., BARA T., BARA T. JR, KADAR Z., MOLNAR C., KOVECSI A., JUNG I., Cancer. Biother. Radiopharm., 29,2014,nr.7,p.295297

32.ULICH TR, DELCASTILLO J, KEYS M, GRANGER GA, NI RX., J. Immunol., 139,1987,nr.10,p.3406-3415

33.ULICH TR, DEL CASTILLO J, GUO KZ., Blood. 73,1989,nr.1,p.108-110.

34.KUSUMANTO YH, DAM WA, HOSPERS GA, MEIJER C, MULDER NH., Angiogenesis. 6,2003,nr.4,p.283-287.

35.SHAMAMIAN P, SCHWARTZ JD, POCOCK BJ, MONEA S, WHITING D, MARCUS SG, MIGNATTI P., J. Cell. Physiol., 189,2001,nr2,p.197-206.

36.VIERS BR, THOMPSON RH, BOORJIAN SA, LOHSE CM, LEIBOVICH BC, TOLLEFSON MK., Urol. Oncol., 32,2014,nr.8,p.12771284 .

37.AGIZAMHAN S, QU F, LIU N, SUN J, XU W, ZHANG L, GUO H, GAN W., BMC Urol., 18,2018,nr.1,p.60, doi: 10.1186/s12894-0180374-Z

39.BADAU D., BADAU A., Int. J. Environ. Res. Public Health., 15,2018,nr.12,p.1-20

39.BADAU A., BADAU D., CLIPA A., Mat.Plast., 55, no. 4, 2018, p.600-602

40.SHEN L, ZHANG H, LIANG L, LI G, FAN M, WU Y, ZHU J, ZHANG Z., Radiat. Oncol., 9,2014,p.295, doi: 10.1186/s13014-014-0295-2. 41.MURESAN M, MURESAN S, BRINZANIUC K, VOIDAZAN S, SALA D, JIMBOREAN O, AL HUSSEIN H, BARA TJR, POPESCU G, BORZ C, NEAGOE R., Medicine, 96,2017,nr.5,p.e6006.

42.NEAGOE RM, MUREȘAN M, VOIDĂZAN S, PAȘCANU I, POP RADU C, SALA D., Endokrinol. Pol., 67,2016,nr.2,p.202-209.

43.LI H, SONG J, CAO M, WANG G, LI L, ZHANG B, LI Y, XU W, ZHENG J., Int. Immunopharmacol., 40,2016,p.327-331

44.ADAMSSON ERYD S, SMITH JG, MELANDER O, MELANDER O, HEDBLAD B, ENGSTRÖM G., Arterioscler. Thromb. Vasc. Biol., 32,2012,nr.2,p.533-539

45.BALTA S, CAKAR M, DEMIRKOL S, ARSLAN Z, AKHAN M., Clin. Appl. Thromb. Hemost., 19,2013,nr.5,p.579, doi: $10.1177 / 1076029612475023$

46.FURUNCUOĞLU Y1, TUlgAR S, DOGAN AN, CAKAR S, TUlGAR YK, CAKIROGLU B., Eur. Rev. Med. Pharmacol. Sci., 20,2016,nr.7,p.1300-1306

$\overline{\text { Manuscript received: } 21.02 .2019}$ 